\title{
Geographic Information System of Primary Carbon Deposit of Mangrove Forest in Merauke District, Indonesia
}

\author{
Fransiskus Xaverius ${ }^{1 *}$, Stanly Hence Dolfi Loppies ${ }^{1}$, Kiman Siregar ${ }^{2,3}$, \\ Zane Vincēviča-Gaile ${ }^{4}$, and Praptiningsih Gamawati Adinurani ${ }^{5}$ \\ ${ }^{1}$ Department of Information System, Faculty of Engineering, Musamus University, \\ Jl. Kamizaun Mopah Lama, Merauke 99611, Papua, Indonesia \\ ${ }^{2}$ Department of Agricultural Engineering, Faculty of Agriculture, Syiah Kuala University, \\ Jl.Tgk. Hasan Krueng Kalee No.3, Kopelma Darussalam, Banda Aceh 23111, Indonesia \\ ${ }^{3}$ Indonesian Life Cycle Assessment Network (ILCAN), Kawasan Puspitek Serpong, \\ Geographic Information Science (GIScience) at Friedrich Schiller University, Jena, \\ GermanyTangerang, Banten 15314, Indonesia \\ ${ }^{4}$ Department of Environmental Science, University of Latvia, Jelgavas Street 1, Room 302, \\ Riga LV-1004, Latvia \\ ${ }^{5}$ Department of Agrotechnology, Merdeka University of Madiun, Jl. Serayu No.79, \\ Madiun 63133, East Java, Indonesia
}

\begin{abstract}
Emission factors with increasing carbon dioxide $\left(\mathrm{CO}_{2}\right)$ originating from various human activities are one of the causes of global climate change. The mangrove forest is a type of plant that has a great ability to absorb carbon in the atmosphere and store it in biomass through photosynthesis. Merauke Regency has 20 separate parts based on regional administration, but primary Mangrove forests are only found in ten regions (district). The results of research carried out using geographic information systems (GIS) in processing primary Mangrove forest data based on 2016 land cover map data in Merauke district, the area of primary mangrove forest reaches 184.402 ha, which is spread in various regions. With carbon deposits reaching $21536333 \mathrm{t} \mathrm{ha}^{-1}$-Carbon and Emission carbon dioxide reach $409758.04 \mathrm{t} \mathrm{ha}^{-1}$.
\end{abstract}

Key words: Carbon stock, climate change, spatial map, tropical mangrove.

\section{Introduction}

Emission factors originating from human activities are one of the biggest contributors to carbon dioxide emissions that cause global warming (Greenhouse gas emissions Mangrove forest is a type of plant that can absorb and store carbon in the atmosphere through

\footnotetext{
* Corresponding author: frans@unmus.ac.id
} 
photosynthesis. Merauke Regency is one of the government areas in the province of Papua, with coordinates and latitude-longitude, -8.499112, 140.404984 / ${ }^{\circ} 29^{\prime} 56.8032$ " S, $140^{\circ} 24^{\prime}$ 17.9424" E, with an area of $44037 \mathrm{~km}^{2}$ and the area of primary Mangrove forests based on land cover maps reaching 184402 ha [1].

The land cover map is a process of data processing by utilizing satellite imagery in performing data calcifications so as to produce data on land cover, which consists of various types, including primary forest cover [2]. Data processing satellite images that produce land cover maps are capable of using geographic inf 'ormation systems because the results obtained are faster, the time efficiency is more optimal, the economic value is lower, and the scope is wider [2]. Carbon deposits can be seen from the results of land use studies using remote sensing and Geographic Information Systems (GIS) [3].

Geographical information system is a spatial information system that involves interaction between hardware, software, spatial and human data. GIS is also a computerbased system capable of collecting storing, analyzing, and presenting data in the form of information in spatial form. GIS is also able to be applied in analyzing the level of increase in emissions in industrial areas [4].

In the development of GIS, many are used in various sectors, including in analyzing the level of increase in carbon emissions based on patterns or forms of processing. Issues of global warming become very important and interesting and are of concern to the world because it concerns the survival of all living things [5]. It is also a concern of the Indonesian government in low emissions development planning [6]. This study aims to display information about carbon deposits in primary mangrove forests using land cover maps that are processed by utilizing geographic information system capabilities in displaying information.

\section{Theoretical Framework}

\subsection{Geographic information system}

Geographic Information System is a computer-based spatial system with the ability to collect data, store data, analyze data, and be able to present data in information in a spatial form. In the current development of technology and information GIS is often used to display data and information in planning and processing forest land in carrying out sustainable development [7]. Spatial data and information that is freely accessible (open source) provided by the Open Geospatial Consortium (OGC) so that it makes it easier for users both individuals and organizations to develop it based on needs [2].

GIS is a combination of databases in classifying and storing geospatial data with large files or data sizes. To be able to find out the relationship between each attribute, it is necessary to add a layer or layer to the map to describe the relationship of the geospatial data inside, which will be displayed in the form of a map. Thus, the database design becomes the most important part in the processing of spatial data that connects each attribute. Interrelated or related layers can store different attributes. Each layer stores data based on spatial data attribute data, which will be exported into MYSQL. Pair the tables containing non-spatial information stored in the database with the same spatial data, so that spatial data and non-spatial data can be related (Figure 1). 


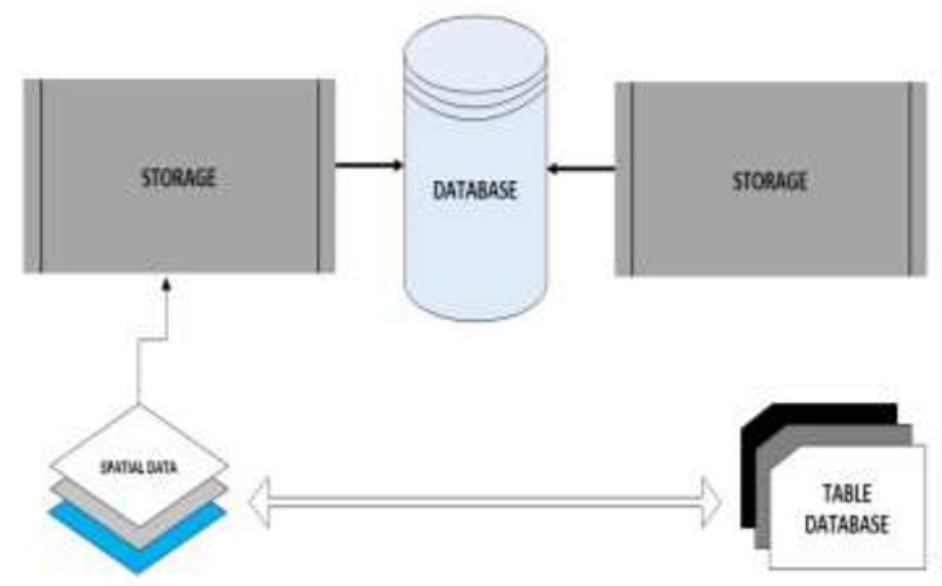

Fig. 1. The relationship between objects and their attributes.

\subsection{Processing of spatial data}

Spatial data processing uses the QGIS Desktop application 2.18.20 and GIS Arc 10.2. Land cover map data obtained from the Regional Government of Merauke Regency, the type of land cover map used is the result of Digitization carried out by the local government in 2016. The process of processing spatial data, in this case, the processing of land cover map data is by overlapping (overlay) between administrative maps and land cover maps. After that, technique of removing other types of land cover using the clip process was used. After the process was completed, the next step was to separate the primary forest cover land map in each area using Marge tools. after all regions have been grounded based on the administration of the most recent stage is to calculate the primary mangrove forest area using Geometry Calculator, the area calculated using unit [2].

\subsection{Calculation of carbon deposits}

The calculation of carbon deposits in primary mangrove forests in several regions in the district of Merauke is done by combining or combined by converting the value of the primary area of primary mangrove forest with a factor of vegetation volume [8]. The total amount of carbon obtained is multiplied by the carbon conversion factor. Details are shown in the following Equation (1), Equation (2), Equation (3), and Equation (4) [9].

Total Vegetation Volume $=$ Vegetation volume $\times 1.454 \times 0.396$

Total Biomass

$=$ Area of vegetation cover $\times$ Total vegetation volume

Total Carbon

$=$ Total biomas $\times 0.5$

Total $\mathrm{CO}_{2}$

$$
=\text { Total carbon } \times 3.6667
$$

\section{Methodology and design system}

Geographical information systems for calculating carbon deposits in primary mangrove forests in Merauke Regency are calculated based on the analysis of needs obtained from the 
Merauke district Regional Planning and Development Agency (BAPPEDA) in the form of regional administrative data, land cover data and area data [10]. Details are displayed in the form of flowcharts and flowcharts and information system frameworks [9]. The flowchart for calculating carbon deposits in primary mangrove forests can be seen in Figure 2.

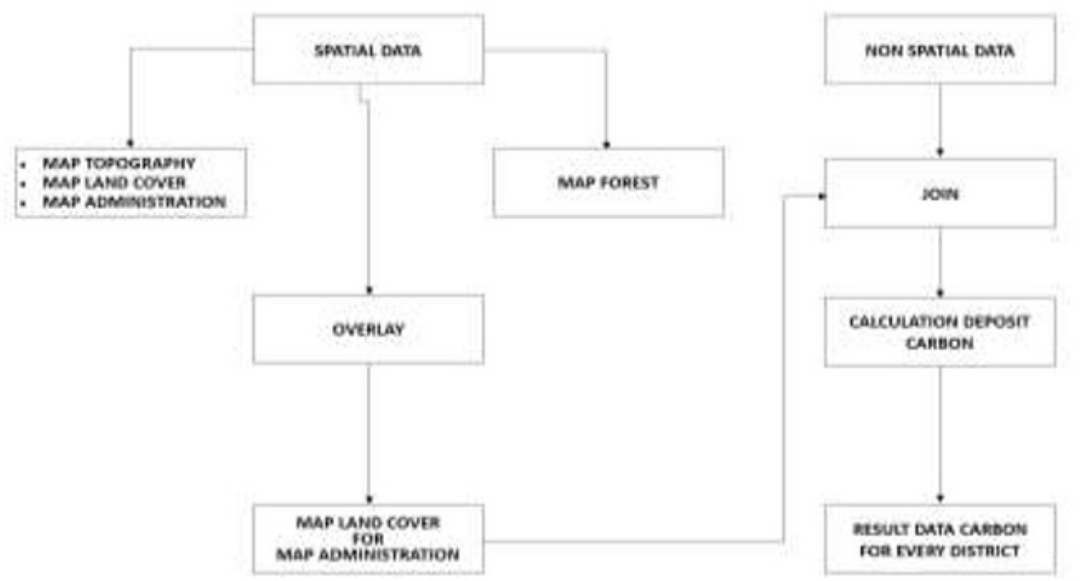

Fig. 2. Flowchart for carbon stock calculations

The calculation of carbon deposits, as shown in Figure 2, is the flow of the carbon deposit calculation process based on the 2016 land cover map. The process of analyzing and calculating carbon deposits begins with the process of collecting spatial data and nonspatial data. Spatial data consists of topographic maps, land cover maps, and administrative maps, while non-spatial data contains the area, carbon storage data, and data on primary mangrove forests.

\subsection{Flowchart information system}

The flowchart information system is a flow of research framework in the processing process until the information stage is displayed. In detail, it can be seen in Figure 3.

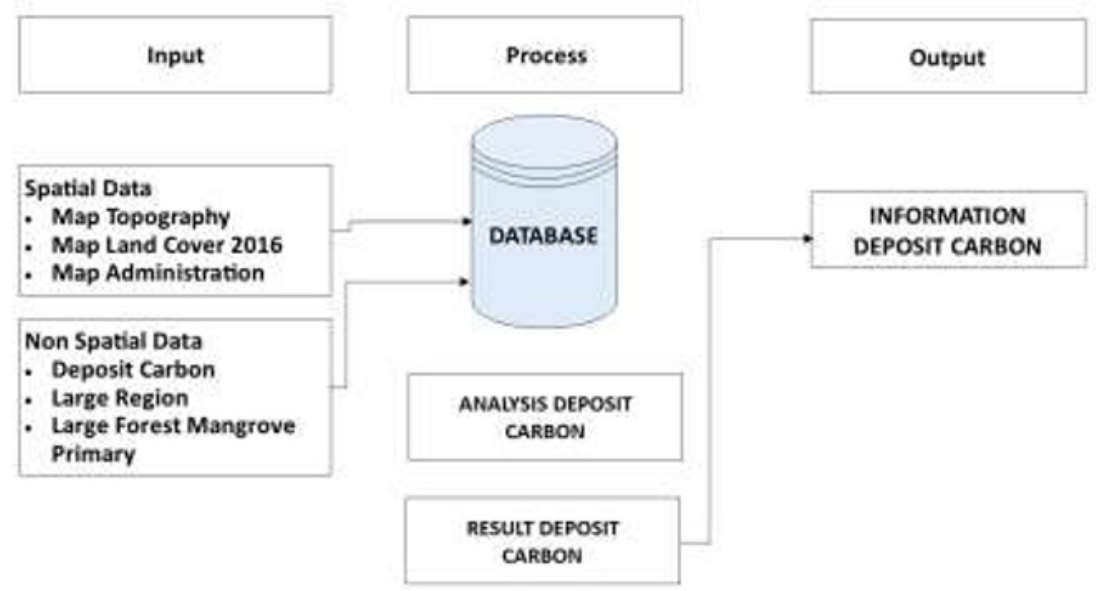

Fig. 3. Flowchart of information system. 
Table 1. Database table

\begin{tabular}{cccc}
\hline Name & Type & Length & Detail \\
\hline ID & String & 5 & ID \\
Nameobj & String & 20 & Name Object \\
Forest type & integer & 10 & Forest Type \\
Large areas & Real & 20.3 & Large Area \\
Large forest & Real & 20.3 & Large Forest \\
& & & Change \\
Cha_CO_1 & Real & 20.3 & CO ha ${ }^{-1}$ \\
& & & Change CO \\
Cha_CO_2 & Real & 20.3 & $\mathrm{tha}^{-1}$ \\
& & & $\mathrm{Change}^{-3}$ \\
Cha_CO2_1 & Real & 20.3 & $\mathrm{CO}_{2}$ ha $^{-1}$ \\
& & & $\mathrm{Change} \mathrm{CO}_{2}$ \\
Cha_CO2_2 & Real & 20.3 & $\mathrm{tha}^{-1}$ \\
Year & Real & 20.3 & Year $^{2}$
\end{tabular}

In the flowchart Information system, input data is consisting of spatial data and nonspatial data. Spatial data contains map topographic, map land cover year 2016, and map administration, while non-spatial data contains data on carbon, large region, and large forest primary mangrove. In the process section, there is a database that will be used as a storage place for spatial data and non-spatial data after the data has been processed in one subsequent database, carbon deposit analysis in the analysis process contains the calculation process of carbon savings per region. Moreover, the last step is the output, which is the result of calculating carbon deposits. The design database table is shown in Table 1. It explains the database design based information system design for deposit carbon with Id, Name object, Forest Type, Large area, Large forest, Carbon change based standart deposit ha ${ }^{-1}$, total carbon change, and data retrieval in a year.

\section{Result and discussion}

\subsection{Result}

The results of the study of the calculation of forest area and carbon deposits in primary mangrove forests are shown in Table 2 and Table 3, and Figure 4. The results of the calculation of carbon emissions produced by primary mangrove forests also displayed. The results of the calculation of carbon emissions are shown in Table 4 and Figure 5, and all measurement results are displayed in graphical form and can be seen in Figure 6, and the output system can be seen in Figure 7. 
Table 2. Table of Area and Area of Primary Mangrove Forest

\begin{tabular}{lll}
\hline Object name & Large area (ha) & Large Forest (ha) \\
\hline Naukenjerai & 905.86 & 112 \\
Merauke & 1445.63 & 1.195 \\
Kimam & 4630.30 & 65.815 \\
Waan & 2868.06 & 71.200 \\
Semangga & 326.95 & 1.000 \\
Malind & 490.60 & 2.034 \\
Kurik & 977.05 & 2.817 \\
Ilwayab & 1999.08 & 14.615 \\
Tabonji & 5416.84 & 24.658 \\
Ngguti & 3554.62 & 957 \\
\hline
\end{tabular}

Table 3. Results of calculation of carbon deposits

\begin{tabular}{lll}
\hline Object name & Large (ha) & Forest deposit carbon $\left(\mathrm{t} \mathrm{ha}^{-1}\right)$ \\
\hline Naukenjerai & 112 & 13038 \\
Merauke & 1195 & 139578 \\
Kimam & 65815 & 7686546 \\
Waan & 71200 & 8315446 \\
Semangga & 1000 & 116762 \\
Malind & 2034 & 237536 \\
Kurik & 2817 & 328962 \\
Ilwayab & 14615 & 1706922 \\
Tabonji & 24658 & 2879791 \\
Ngguti & 957 & 111751 \\
\hline
\end{tabular}




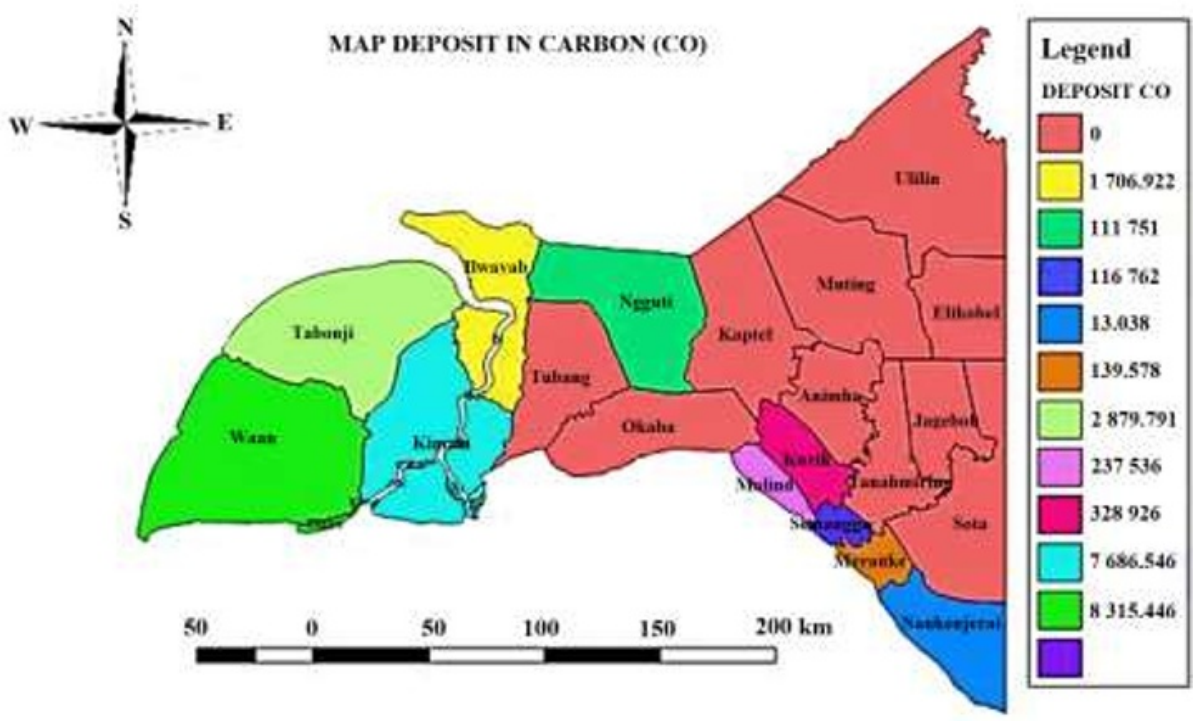

Fig. 4. Map deposit in carbon (CO)

Table 4. The results of the calculation of Carbon dioxide emissions

\begin{tabular}{lll}
\hline Object name & Deposit carbon $\left(\mathrm{t} \mathrm{ha}^{-1}\right)$ & Emission carbon dioxide $(\mathrm{t})$ \\
\hline Naukenjerai & 13038 & 47805.86519 \\
Merauke & 139578 & 511791.7914 \\
Kimam & 7686546 & 28184259.16 \\
Waan & 8315446 & 30490247.17 \\
Semangga & 116762 & 428133.057 \\
Malind & 237536 & 870972.1176 \\
Kurik & 328962 & 1206205.058 \\
Ilwayab & 1706922 & 6258769.85 \\
Tabonji & 2879791 & 10559330.1 \\
Ngguti & 111751 & 09758.0423 \\
\hline
\end{tabular}




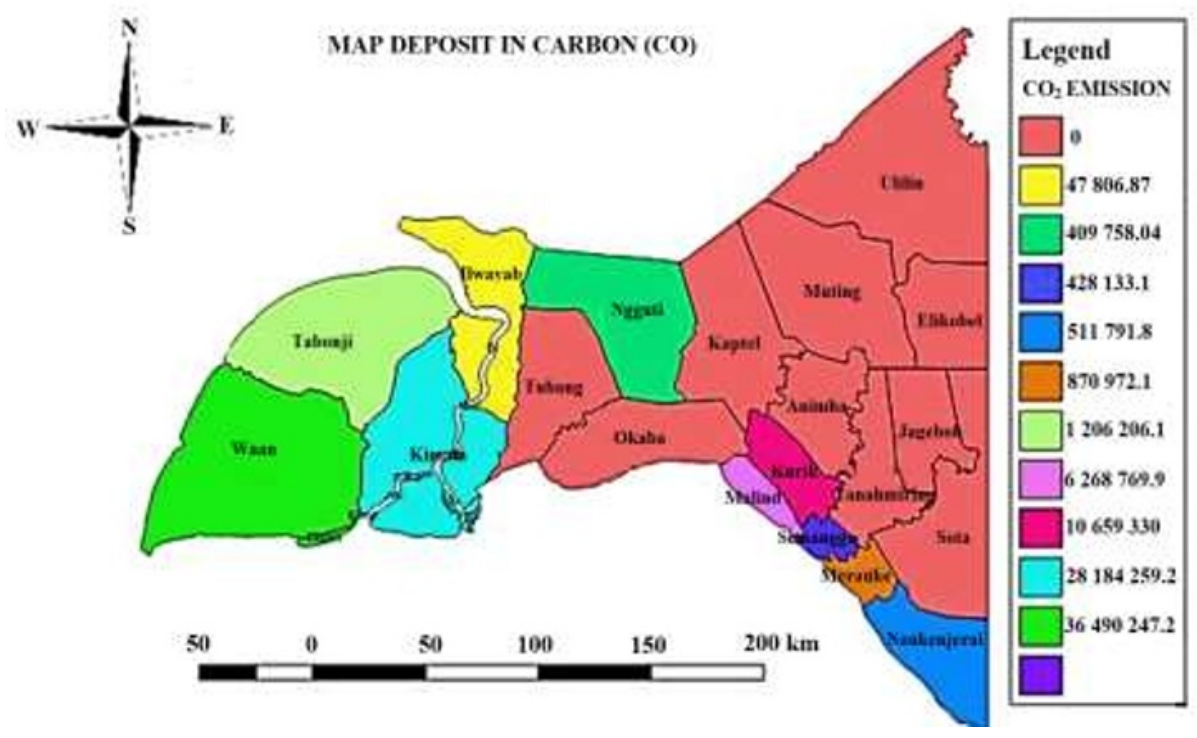

Fig. 5. Map of $\mathrm{CO}_{2}$ emission in Merauke.

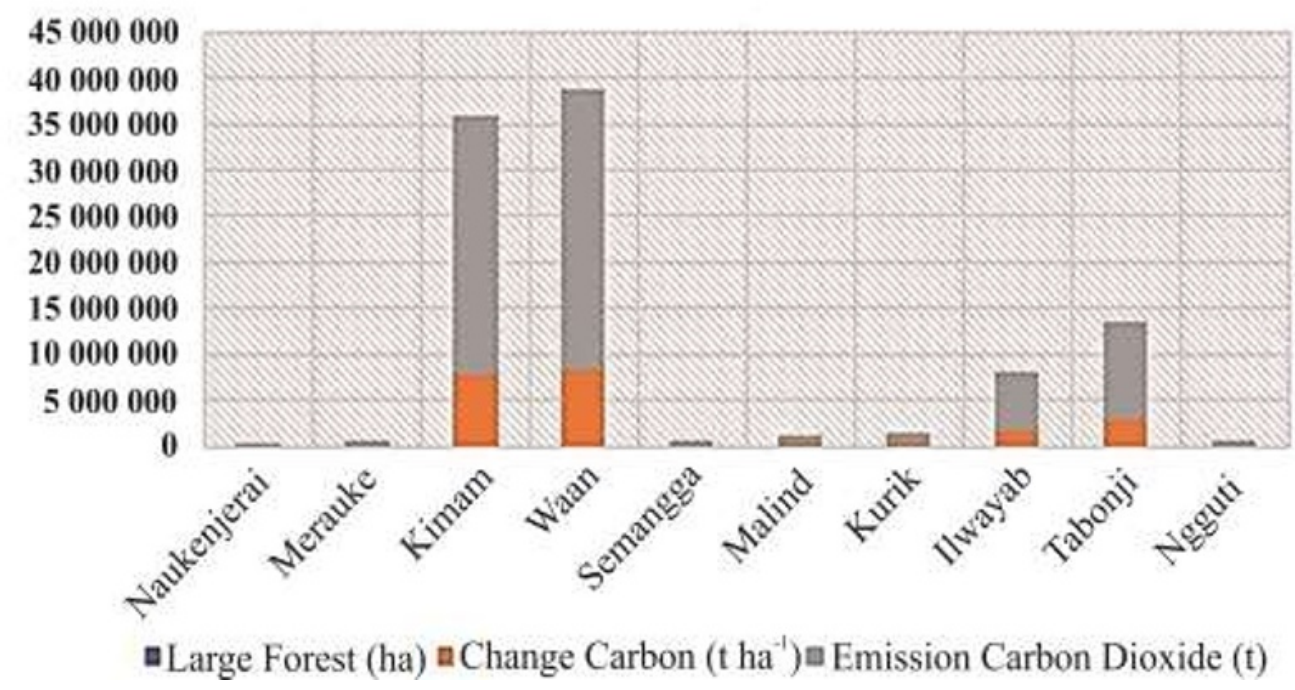

Fig. 6. Chart of $\mathrm{CO}$ dan $\mathrm{CO}_{2}$ 


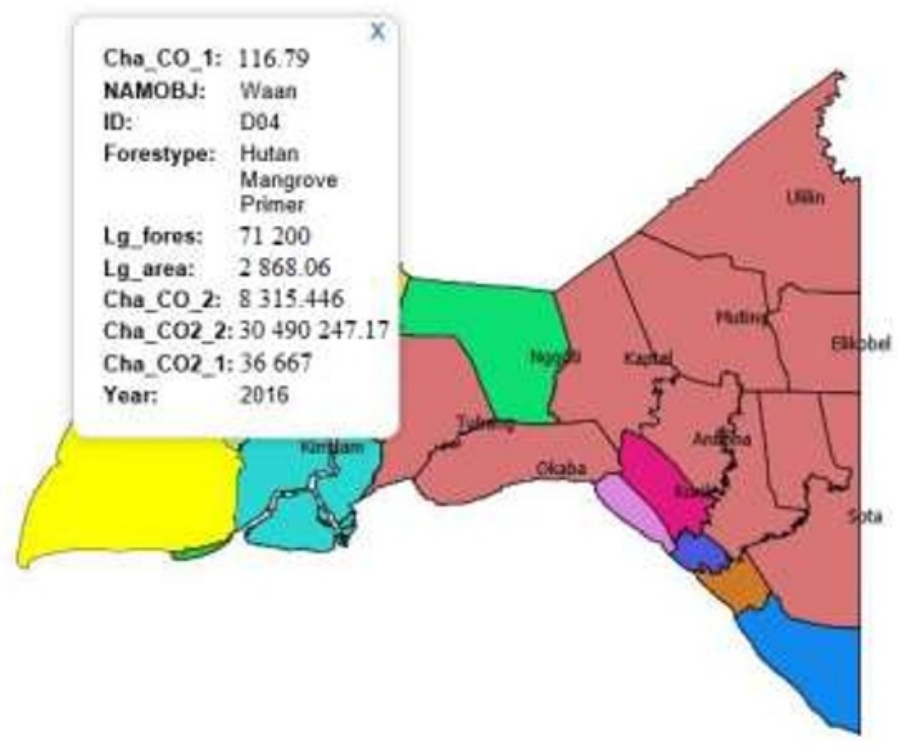

Fig. 7. Output system using ArcGIS 10.2 and Ogis 2.18.20.

\subsection{Discussion}

The results of the calculation of carbon deposits carried out using the GIS methodology by combining ArcGIS 10.2, and Qgis 2.18.20 software is depicted in Figure 7. A qualitative assessment from the results was undertaken by carrying out the user interviews, whose responses indicate that the carbon deposit calculation process with this technique is very helpful in terms of cost reduction and shorter time efficiency and ability to produce good information.

\section{Conclusion}

Based on the results of the research conducted, it can be concluded that Merauke Regency has a very extensive mangrove forest, thus affecting the number of carbon deposits and emissions that can be absorbed from the atmosphere from various sources. The results of our study show that the largest amount of carbon uptake is found in the wan district with numbers reaching $8315446 \mathrm{t}$ and carbon emissions absorbed reaching $30490247.17 \mathrm{t}$, and the total carbon deposits total $21536333 \mathrm{t} \mathrm{ha}^{-1}$ Carbon and Emission carbon dioxide reaching $409758.04 \mathrm{tha}^{-1}$.

\section{References}

1. F. Xaverius, R. Gernowo, K. Adi, Int. J. Comput. Appl., 180,51:42-47(2018). https://www.semanticscholar.org/paper/Geographic-Information-System-CarbonDevelopment-on-Xaverius-Gernowo/d0c69700c143746aa0b3fbb017bee7369fbbe4f1

2. C. Lloyd. Spatial data analysis: An introduction for GIS users. Oxford University Press, New York (2010). p. 86-128.

https://books.google.de/books?hl=en\&lr=\&id=7WGcAQAAQBAJ\&oi=fnd\&pg=PR7 $\underline{\text { dq }=\text { Introduction }+ \text { of }+ \text { GIS \&ots }=\mathrm{M}-}$ 
_gyevWSt\&sig=VQHVQEXo81vea2lcYjPmvZFH-

9A\&redir_esc $=\mathrm{y} \# \mathrm{v}=$ onepage $\& \mathrm{q}=$ Introduction $\% 20 \mathrm{of} \% 20 \mathrm{GIS} \& \mathrm{f}=$ false

3. A. Tosiani. Buku kegiatan serapan dan emisi karbon [Book on carbon sequestration and emissions activities] [Online] from.

http://appgis.dephut.go.id/appgis/download/Pemantauan\%20Hutan\%20Nasional/Buku \%20Pemantauan\%20Emisi\%20dan\%20Serapan\%20Karbon_2015 Tosiani.pdf (2015). [Accessed on 15 October 2019]. [in Bahasa Indonesia]

4. K.A.R.S. Perera dan M. D. Amarasinghe Geoderma, 347:80-89(2019). https://www.sciencedirect.com/science/article/pii/S0016706118320056

5. Q.L. Xu, K. Yang, S.Y. Peng, J. Sheng, J.H. Xiong. Study on an evaluating model of forestry carbon sequestration capacity by using GIS. The 18th International Conference on Geoinformatics: GIScience in Change (Beijing, China 2010). Geoinformatics (2010). https://ieeexplore.ieee.org/document/5567606/

6. Z. Jalali. International Journal of Mining Science and Technology, 26,6:959966(2016). https://www.sciencedirect.com/science/article/abs/pii/S209526861630088X

7. S. Hence, D. Loppies, G.J. International Journal of Mechanical Engineering and Technology (IJMET), 9,12:177-183(2018).

http://eprints.unmus.ac.id/312/1/04_IJMET_09_12_021_GEOGRAPHIC_INFORMAT ION_SYSTEM.pdf

8. BSNI. Klasifikasi penutup lahan vol. SNI 7645 [Online] from http://appgis.dephut.go.id/appgis/download/Pemantauan\%20Hutan\%20Nasional/SNI 2010_7645_Klasifikasi_penutup_lahan.pdf (2010). [Accessed on 15 October 2015]. [in Bahasa Indonesia].

9. G. Mardiatmoko, Biota 17,(1):35-44(2012). [in Bahasa Indonesia].

https://www.academia.edu/32608933/PEMETAAN_DISTRIBUSI_BIOMASSA HUT AN_DAN_KAITANNYA_DENGAN_SUHU_DAN_INTENSITAS_CAHAYA_MEL ALUI_PENDEKATAN_SIG

Kelompok Kerja Teknis Inisiatif Pembangunan Rendah Emisi (POKJA TIPRE). Strategi perencanaan tata guna lahan mendukung pembangunan rendah emisi Kabupaten Merauke [Land use planning strategy for low emissions development planning in Merauke Regency]. F. Johana, B. Zein, Isnurdiansyah, Suyanto (Eds). Pokja TIPRE Kabupaten Merauke, Merauke (2017). pp. 39-43. [in Bahasa Indonesia]. https://docplayer.info/47113373-Strategi-perencanaan-tata-guna-lahan.html 